\title{
THE EFFECT OF CHANGES IN THE COMPLEXLY DEFINED THERMAL ENVIRONMENT ON BODY AND SKIN TEMPERATURE AND ENERGY METABOLISM IN PIGLETS
}

\author{
V. KOTRBÁČEK \\ Department of Physiology, University of Veterinary Science, 61242 Brno
}

Received October, 31983

\begin{abstract}
Kotrbáček, V.: The Effect of Changes in the Complexly Defined Thermal Environment on Body and Skin Temperature and Energy Metabolism in Piglets. Acta vet. Brno, 53, 1984: $31-39$.

The body temperature $\left(T_{B}\right)$ of piglets aged 1 to 25 days did not change significantly with changes in the cooling effect of the metabolic chamber from 40 to $60,90,120$ and $150 \mathrm{~W} \cdot \mathrm{m}^{-2}$ as determined by the sensor of an electric dynamic katathermometer (EDK). Only in piglets aged 1 to 5 days a downward trend of $T_{B}$ was observed. The skin temperature $\left(T_{S}\right)$ of the piglets, however, decreased significantly under these conditions up to the age of 10 days even if they were warmed from the floor $34{ }^{\circ} \mathrm{C}$ warm. Heating the floor to 36 or $38^{\circ} \mathrm{C}$ led to rapid rise and stabilization of $T_{B}$ at a level reached in thermoneutral environment even with high cooling effect of the chamber $\left(150\right.$ and $\left.180 \mathrm{~W} . \mathrm{m}^{-2}\right)$. In piglets laying on the floor heated to $40^{\circ} \mathrm{C}$ the $T_{B}$ significantly increased above this level.

Heat production (HP) of the piglets aged 1 to 5 days was lowest at the cooling effect of 60 and $90 \mathrm{~W} . \mathrm{m}^{-2}$. It rose significantly with the cooling effect increasing to 120 and $150 \mathrm{~W} . \mathrm{m}^{-2}$ but also with its drop to $40 \mathrm{~W} \cdot \mathrm{m}^{-2}$. Piglets aged 6 to 10 days had their lowest heat production at the cooling effect of 90 and $120 \mathrm{~W} . \mathrm{m}^{-2}$. At the cooling effect lowered to $60 \mathrm{~W} . \mathrm{m}^{-2}$ their heat production started to rise and at $150 \mathrm{~W} \cdot \mathrm{m}^{-2}$ it was significantly higher.

The heat production of piglets aged 11 to 15 days rose significantly only at the cooling effect of $180 \mathrm{~W} . \mathrm{m}^{-2}$; the heat production of older animals was no more affected by the cooling effect of the chamber.

In piglets resting on the floor heated to $34^{\circ} \mathrm{C}$ a rapid fall occurred in heat production even at high cooling effect of the chamber during their first two weeks of life. With rising floor temperature their heat production continued to fall so that on the floor heated to $38^{\circ} \mathrm{C}$ it fell significantly below the level usual in thermoneutral environment. Heating of the floor to $40^{\circ} \mathrm{C}$ did not result in further decrease of heat production.

These results indicate that in a complex thermal environment also the thermoneutral conditions become a more complex parameter requiring an adequate mode of their determination.
\end{abstract}

Thermal environment, body temperature, skin temperature, cooling, thermoneutrality, energy metabolism.

Calorimetric measurements in the laboratory as pointed out by Mount (1978) are usually carried out in standard environment in which the mean radiant temperature and air temperature are equal, natural (free) convection exists, the experimental animal is laying on an insulated floor and it is dry. In such environment the air temperature itself may characterize the thermal conditions. However, the environment in which the animals, including farm animals, live, is. never quite standard. 
Thus, the air temperature is only one among the entire complex of physical factors determining the thermal balance of the organism. Therefore new approaches have been emerging for a more exact and above all more complex determination of the thermal environment and its effects upon the homoiotherm. Some of these approaches are based on summation of separately measured heat flows from the animal bodies through all or at least the main routes of heat expenditure (Mount 1978), others estimate the thermal conditions according to the heat flow measured by a physical model of homoiotherm organism (Česnek, Novák 1978).

As this way proved very efficient in determination the dynamically changing thermal conditions in farrowing houses (Kotrbáček $1979 \mathrm{ab}$ ) we decided to use it in combination with measurement of heat production also in the present experiment with piglets.

\section{Materials and Methods}

In eight Large White piglets aged 1 to 5,6 to 10,11 to 15,16 to 20 and 21 to 26 days we determined the $\mathrm{O}_{2}$ consumption and $\mathrm{CO}_{2}$ production using an automatic gas analyzer (Spirolyt II made by VEB Innkalor Dessau, GDR). Simultaneously, $T_{B}$ of the animals was measured with a mercury

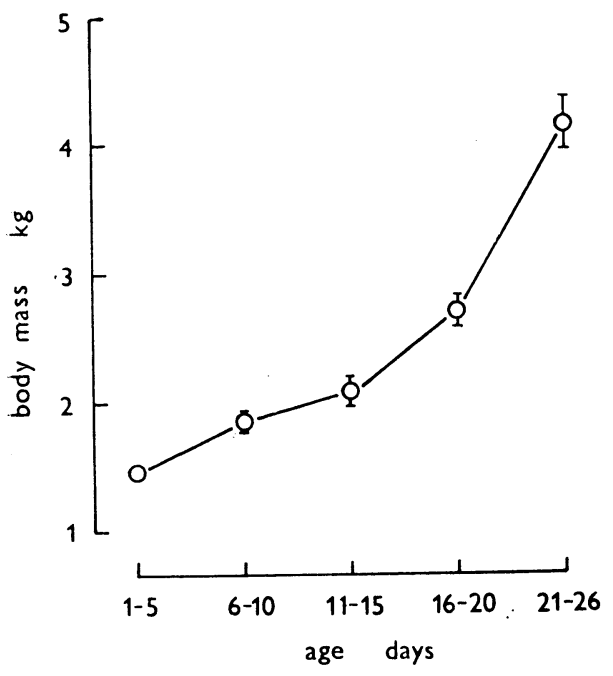

Fig. 1. Changes in live body mass of the experimental piglets thermometer inserted $5 \mathrm{~cm}$ deep in the rectum, and skin temperature was measured by a thermistor in the hip, rib and shoulder blade regions. The piglets were weaned on the second day of life and fed a semisynthetic high-fat diet (Holub 1964 a), and reared under thermal conditions as recommended by the Czechoslovak norm ON 734517 (1976). The increase in live mass of piglets corresponded to current growth rates of this breed (Fig. 1).

Prior to the measurement proper each piglet was placed in the metal metabolic chamber $30 \times 20 \times 50 \mathrm{~cm}$ in size which was immersed in a water bath enabling to maintain or change the thermal conditions inside the chamber. The floor of the chamber had a double bottom the temperature of which could be adjusted as required. The thermal conditions of the chamber were determined by means of the electric dynamic katathermometer (EDK) (Česnek, Novák 1971). The EDK recorded heat flow density (HFD) from the surface of the EDK sensor heated to a constant temperature of $37^{\circ} \mathrm{C}$. HFD represents the heat loss related to a surface unit of the sensor and expresses the cooling effect of the environment. It comprises not only the effects of air temperature and movement but also the effect of thermal radiation and provides thus a more complex information about the thermal conditions of the environment.

The thermal conditions of the chamber controlled in this way were gradually changed in the first part of the experiment. The experimental procedure was as follows: the piglet was placed in the chamber with the cooling effect of $40 \mathrm{~W} \cdot \mathrm{m}^{-2}$ (as measured on the EDK sensor). After a 30-minute adaptation, the $\mathrm{O}_{2}$ consumption and $\mathrm{CO}_{2}$ production by the piglet was measured for another 30 minutes. Thereafter the animal was removed and its rectal and skin temperatures were recorded. The animal was then placed back in the chamber the cooling effect of which had meanwhile been increased to $60 \mathrm{~W} . \mathrm{m}^{-2}$. The measurements were carried out as described above and were then repeated at cooling effects of $90,120,150$ and in some cases also $180 \mathrm{~W} . \mathrm{m}^{-2}$.

In the following part of the experiment, the cooling effect of the chamber was kept constant at $150 \mathrm{~W} \cdot \mathrm{m}^{-2}$ or $180 \mathrm{~W} . \mathrm{m}^{-2}$ while the wooden insulation material on the floor on which the piglet was laying during the previous measurements was removed and the floor was heated to $34,36,38$ and $40{ }^{\circ} \mathrm{C}$. The $\mathrm{O}_{2}$ consumption, $\mathrm{CO}_{2}$ production, rectal and skin temperatures were measured as previously described. The results were evaluated by Student's t-test. 


\section{Results}

The mean body temperature of 1-to 5 -day old piglets ranged about $38^{\circ} \mathrm{C}$. A gradual increase of the cooling effect of the chamber up to $150 \mathrm{~W} . \mathrm{m}^{-2}$ led to its non-significant decrease. A reverse trend was observed when the piglets were warmed from the floor (Fig. 2).

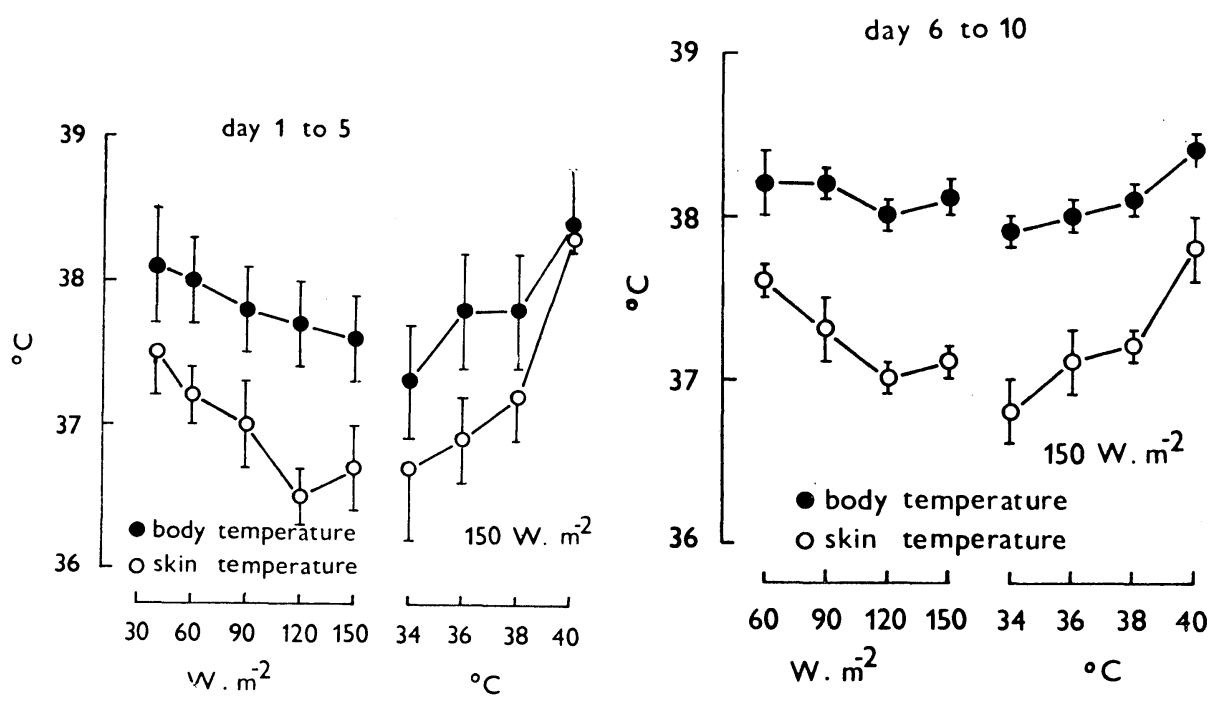

Fig. 2: Body and skin temperature of piglets aged 1 to 5 days in different thermal environments

Fig. 3. Body and skin temperature of piglets aged 6 to 10 days in different thermal environments

The mean skin temperature of the piglets changed significantly. An increase of the cooling effect of the chamber from 40 to $120 \mathrm{~W} . \mathrm{m}^{-2}$ led to its decrease by $1{ }^{\circ} \mathrm{C}(0.01<P<0.02)$. Heating of the floor, however, resulted in its increase even at high cooling effect of the environment. In animals laying on the floor heated to $38{ }^{\circ} \mathrm{C}$ the skin temperature reached the initial values and on the floor heated to $40{ }^{\circ} \mathrm{C}$ it reached almost the level of their rectal temperature $(P<0.01)$.

No remarkable changes in rectal temperature were observed in older piglets with increasing cooling effect of the chamber. It slightly rose in piglets on the floor heated to $40{ }^{\circ} \mathrm{C}(0.02<P<0.05)$. Their skin temperature, however, increased significantly $(P<0.01)$ (Fig. $3,4,5,6)$.

Heat production of 1-to-5-day old piglets was lowest at a cooling effect of the chamber of 60 and $90 \mathrm{~W} . \mathrm{m}^{-2}$ (Fig. 7). It rose rapidly with increasing cooling effect to 120 and $150 \mathrm{~W} . \mathrm{m}^{-2}$ but also with its drop to $40 \mathrm{~W} . \mathrm{m}^{-2}(P<0.01)$. Warming of piglets through the floor heated to $34^{\circ} \mathrm{C}$ caused a decrease in their heat production $(0.02<P<0.05)$. With increasing floor temperature the heat production of piglets further declined so that on the floor heated to $38^{\circ} \mathrm{C}$ it was lower than that found at 60 or $90 \mathrm{~W} . \mathrm{m}^{-2}$. The heat productiom of 6 -to 10 -day old piglets was lowest in an environment with the cooling effect of 90 and 120 W. $\mathrm{m}^{-2}$ (Fig. 8). Its decrease to $60 \mathrm{~W} . \mathrm{m}^{-2}$ caused a non-significant increase of heat production. The cooling effect of $150 \mathrm{~W} . \mathrm{m}^{-2}$ resulted in a significant $(0.02<P<0.05)$ increase in heat production of piglets. Heating the floor to 


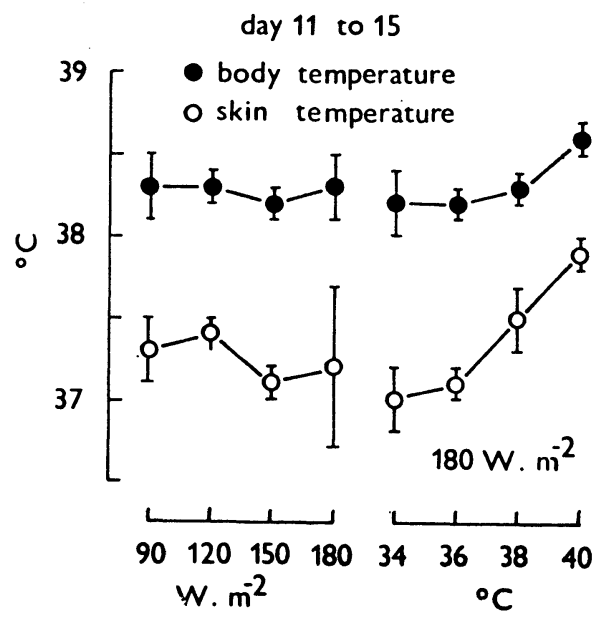

Fig. 4. Body and skin temperature of piglets aged 11 to 15 days in different thermal environments

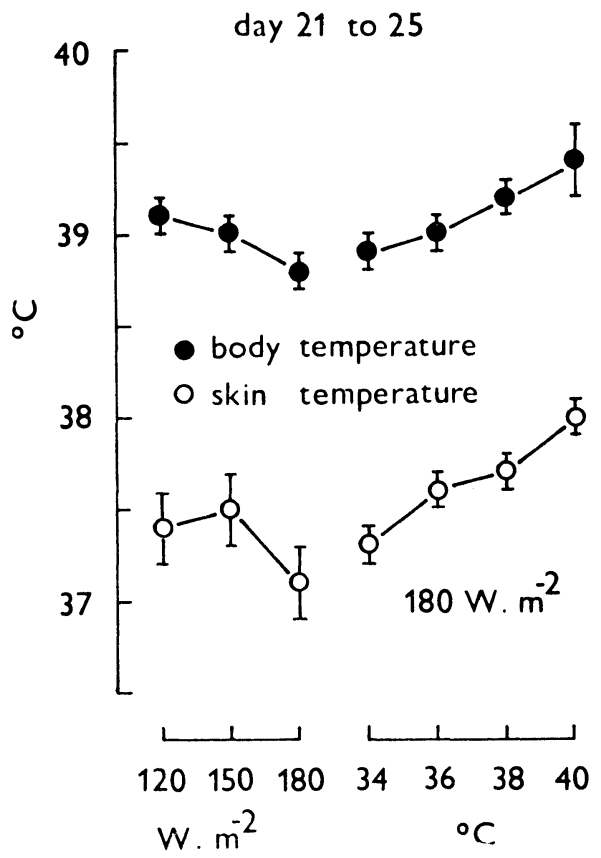

Fig. 6. Body and skin temperature of piglets aged 21 to 26 days in different thermal environments day 16 to 20

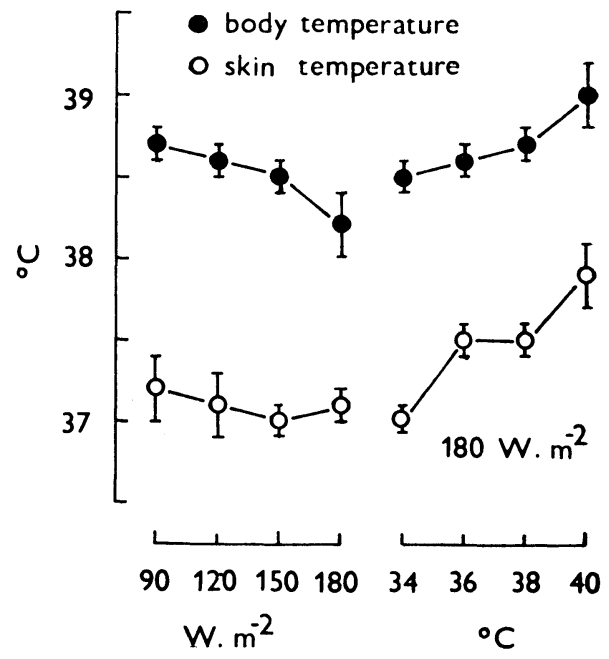

Fig. 5. Body and skin temperature of piglets aged 16 to 20 days in different thermal environments

34 and $36^{\circ} \mathrm{C}$ led to another drop in heat production of piglets to the level obtained in an environment with the cooling effects of $90 \mathrm{~W} . \mathrm{m}^{-2}$ and at the floor temperature of $38^{\circ} \mathrm{C}$ it even fell significantly below this level $(P>$ $<0.01)$. In this phase of the experiment the piglets of all age groups fell regularly asleep.

In piglets aged 11 to 15 days the heat production showed no significant changes at the cooling effect of 90 to $150 \mathrm{~W} . \mathrm{m}^{-2}$ (Fig. 7). It rose slightly at the cooling effect of $180 \mathrm{~W} \cdot \mathrm{m}^{-2}$. The heating of the floor to 34 and $36{ }^{\circ} \mathrm{C}$ produced a decrease in heat production of piglets roughly to the initial level. On the floor heated to $38^{\circ} \mathrm{C}$ their heat production fell significantly $(P<0.01)$ below this level.

Older piglets did not change their heat production appreciably in the course of the experiment (Fig. 8), nevertheless its downward trend was observed with the heating of the floor. 

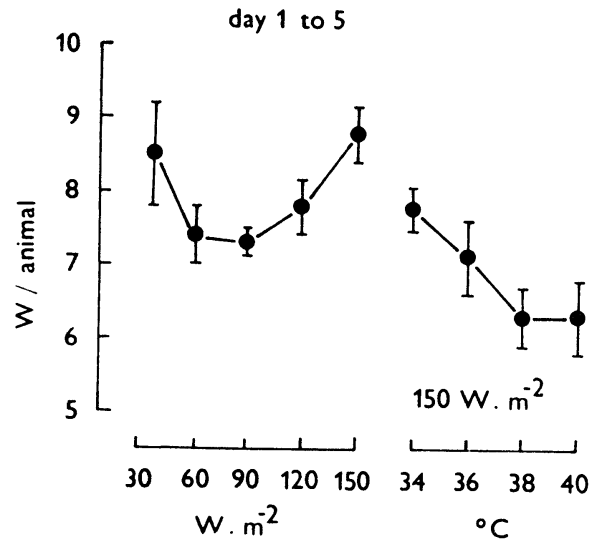

Fig. 7. Heat production of piglets aged 1 to 5 days in different thermal environments

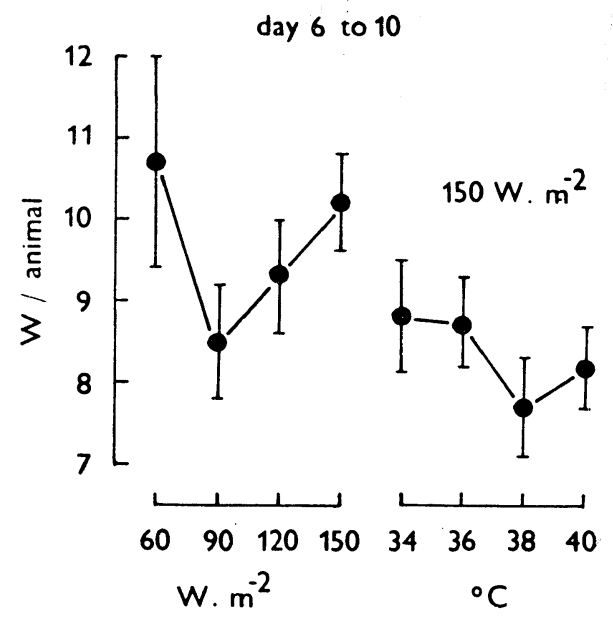

Fig. 8. Heat production of piglets aged 6 to 10 days in different thermal environments

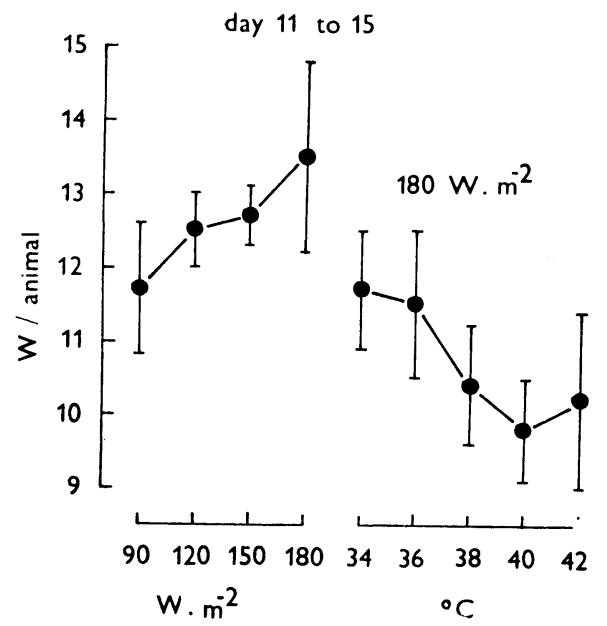

Fig. 9. Heat production of piglets aged 11 to 15 days in different thermal environments

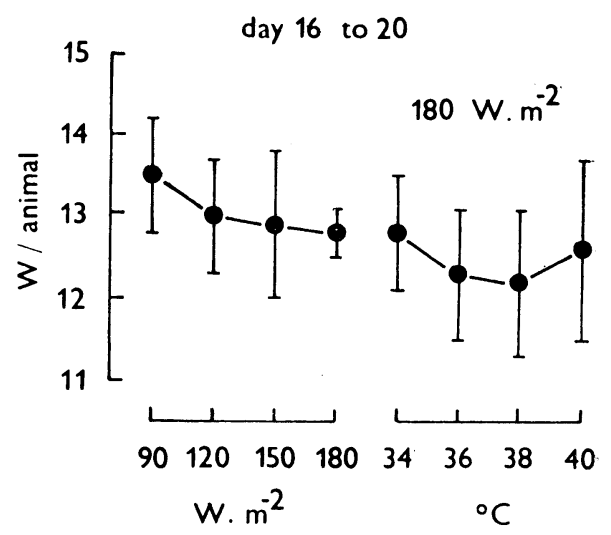

Fig. 10. Heat production of piglets aged 16 to 20 days in different thermal environments

The heat flow density (HFD) from the EDK sensor, as determined in the metabolic chamber, was zero at the air temperature of $37^{\circ} \mathrm{C}$. With decreasing air temperature it gradually increased up to $215 \mathrm{~W} . \mathrm{m}^{-2}$ at $20^{\circ} \mathrm{C}$ (Table 1 ). is

\section{Discussion}

An objective determination of the thermal conditions and thermal comfort is more complicated in an environment in which a complex of thermal factors is operative. This experiment was designed so as to embrace this complex by a single 
parameter to which the basic data on energy metabolism of piglets could be related. We found that the body temperature of piglets was not significantly affected by the increasing cooling effect of the chamber. Only in the youngest piglets, aged 1 to 5 days, it showed a downward trend. This was rapidly corrected by heating the floor to $36^{\circ} \mathrm{C}$. Thus the changes in the thermal environment did not exceed the thermoregulatory capacity of the experimental piglets. This was obviously also due to a relatively short exposure of the piglets to experimental conditions. In agreement with data of other authors, e. g. McGinnis et al. (1981), the skin temperature of our piglets showed a more sensible reaction to

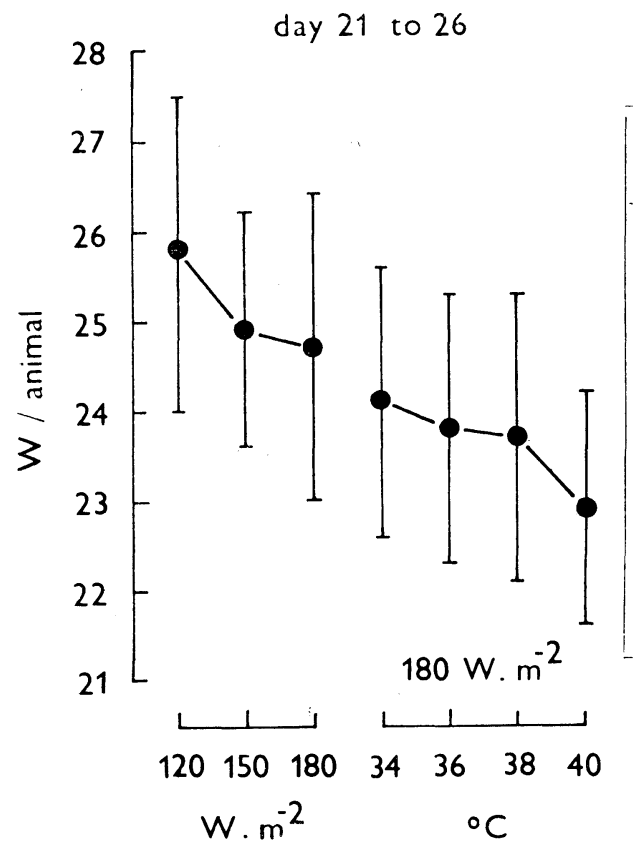

Table 1

Thermal conditions in the metabolic chamber at various ambient temperatures

\begin{tabular}{c|c|}
\hline$T_{\mathrm{a}}$ in metabolic chamber & $\begin{array}{c}\text { Heat flow density of the } \\
{ }^{\circ} \mathrm{C}\end{array}$ \\
$\begin{array}{c}\text { EDK sensor } \\
W \cdot \mathrm{m}^{-2}\end{array}$ \\
37 & 0 \\
36 & 99 \\
35 & 22 \\
34 & 33 \\
33 & 54 \\
32 & 64 \\
31 & 76 \\
30 & 89 \\
29 & 101 \\
28 & 113 \\
27 & 126 \\
26 & 139 \\
25 & 151 \\
24 & 158 \\
23 & 176 \\
22 & 188 \\
21 & 200 \\
20 & 215 \\
\end{tabular}

Fig. 11. Heat production of piglets aged 21 to 26 days in different thermal environments

changes in the thermal conditions. A drop in skin temperature due to increasing cooling effect perceptible until day 10 after birth was always rapidly compensated for by heating the piglets from the floor $36^{\circ} \mathrm{C}$ or $38^{\circ} \mathrm{C}$ warm. Contact with the floor heated to $40{ }^{\circ} \mathrm{C}$ led in majority of piglets to a further, significant increase in skin temperature.

Heat production of piglets aged 1 to 5 days increased with increasing cooling effect of the chamber above $90 \mathrm{~W} . \mathrm{m}^{-2}$. This increase was, no doubt, connected with equilibration of the higher heat losses of piglets as demonstrated also by the development of their body temperature and mainly of their skin temperature.

At the same rate, however, their heat production rose with decreasing cooling effect below $60 \mathrm{~W} . \mathrm{m}^{-2}$ which was obviously the upper limit of the thermoneutral zone. This limit can also be derived from the following consideration. The basal heat production of the youngest piglets was $7.3 \mathrm{~W} /$ animal, i. e. ca $65 \mathrm{~W} . \mathrm{m}^{-2}$ of their body surface. To provide for free heat dissipation at any time the cooling effect of the environment should be kept at least at this level. Our previous 
measurements (Kotrbáček, Holub $1979 \mathrm{ab}$ ) carried out in rearing houses have shown that the cooling effect of the environment e. g. under infrared lamps is due to their thermal radiation usually much lower than the above-mentioned $60 \mathrm{~W} . \mathrm{m}^{-2}$. This demonstrates the acute danger of overheating the piglets even in an environment the mean air temperature of which does not exceed the limits of thermoneutrality.

The piglets aged 6 to 10 days had the lowest heat production in an environment with the cooling effect of 90 to $120 \mathrm{~W} \mathrm{.} \mathrm{m}{ }^{-2}$. A higher cooling effect of the chamber $\left(150 \mathrm{~W} . \mathrm{m}^{-2}\right)$ increased their heat production. The piglets aged 11 to 15 days increased their metabolic rate only in an environment with the cooling effect of $180 \mathrm{~W} . \mathrm{m}^{-2}$, and in older piglets the experimental conditions had no more effect on their heat production. These findings are in agreement with other data documenting the gradual fall of the thermoneutrality limit towards lower ambient temperatures with advancing age of piglets. From our measurements of heat production in the environment with various cooling effects the zones of thermal comfort for the individual age groups of piglets can be calculated which express the relationship of the animal and its environment much more complexly than e. g. ambient temperature alone. Nevertheless, not even data obtained in this way are generally valid as follows from the second part of our experiment in which a different mode of heat supply was used. In piglets aged 1 to 5 days even at high cooling effect of the chamber $\left(150 \mathrm{~W} . \mathrm{m}^{-2}\right)$ the basal heat production was rapidly obtained when the floor was simultaneously heated to $36^{\circ} \mathrm{C}$. The same was true also for 6-to 10-day old and 11-to 15-day old piglets. With these, however, the cooling effect of the chamber environment was increased to 180 $\mathrm{W} . \mathrm{m}^{-2}$. This implies that the piglets warmed from the floor of a certain temperature are able to receive heat by contact efficiently enough so that even relatively high cooling effect of their environment does not impair their thermal comfort. This was also supported by the fact that the piglets had not only not augmented their heat production but, on the contrary, at a floor temperature of $38^{\circ} \mathrm{C}$ they decreased it below the basal level. This finding that cannot be explained only by an overall tranquilization of piglets (those kept in the thermoneutral zone during the first part of the experiment were calm as well), may in our opinion be in context with sleep that regularly occurred in these animals. Our presumption is supported by the data on REM sleep that may be facilitated from periphery by thermal stimuli (Heller and Glotzbach 1980) and may even lead to inhibition of thermoregulation and a decrease of energy metabolism. Especially in young animals it is an important means of energy conservation enabling its utilization for anabolic processes (Horne 1977). In this context it should be emphasized that the primary source of heat for the piglet is its mother and that contact with her is the primary thermal stimulus which also provides a feeling of safety important for the fragile REM sleep. According to our measurements, skin temperatures of the mammary gland in sows oscillated around $38^{\circ} \mathrm{C}$ (Kotrbáček and Nau 1984). The effect of the floor heated to this particular temperature was obviously so prominent because it imitated not only tho heat flow density but also the mode by which heat is provided to piglets under natural conditions.

The results indicate that an objective determination of thermal conditions of the environment and a more exact description, of thermal comfort becomes more complex with increasingly complex character of this environment. 


\section{Vliv změn komplexně definovaného tepelného prostředí na tělesnou teplotu, teplotu kưže a energetický metabolismus selat}

Tělesná teplota (TT) selat 1 až 25 denních se při změnách ochlazovacích vlastností metabolické komory (OVK) vyhřívané vodní lázní, a to na 40 , dále 60 , 90,120 a $150 \mathrm{~W} \cdot \mathrm{m}^{-2}$ zjištovaných na čidle elektrického dynamického katatermometru (EDK), průkazně neměnila. Pouze u selat 1 až 5 denních byl zjištěn její sestupný trend. Teplota kủže (TK) v těchto podmínkách klesala průkazně až do stáŕi 10 dnů, a to i při zahřívání selat z podlážky $34^{\circ} \mathrm{C}$ teplé. Zvýšení teploty podlážky na 36 resp. $38^{\circ} \mathrm{C}$ vedlo i při vysokých OVK 150 resp. $180 \mathrm{~W} . \mathrm{m}^{-2}$ $\mathrm{k}$ rychlému vzestupu a stabilizaci (TK) přibližně na úroveň dosahovanou $v$ termoneutrálním prostředí. Na podlážce $40^{\circ} \mathrm{C}$ teplé se TK průkazně zvyšovala nad tuto úroveň.

Tepelná produkce (TP) selat 1 až 5 denních dosahovala nejnižší úrovně při OVK 60 a $90 \mathrm{~W} . \mathrm{m}^{-2}$. Prủkazně rostla při zvyšování $\mathrm{OVK}$ na 120 a $150 \mathrm{~W}$. m-2, ale též při snížení OVK na $40 \mathrm{~W}$. m-2. Selata 6 až 10denní měla nejnižší TP při OVK 90 a $120 \mathrm{~W} . \mathrm{m}^{-2}$. Při snižení OVK na $60 \mathrm{~W} \cdot \mathrm{m}^{-2}$ měla TP již stoupající trend a OVK $150 \mathrm{~W} \cdot \mathrm{m}^{-2}$ ji zvyšovaly průkazně. U selat 11 až 15 denních se TP průkazně zvyšovala pouze při OVK $180 \mathrm{~W} \cdot \mathrm{m}^{-2}$; TP selat starších změny OVK již neovlivňovaly. Zahřívání selat podlážkou $34^{\circ} \mathrm{C}$ teplou vedlo $\mathrm{v}$ prvých dvou týdnech života $\mathrm{k}$ rychlému poklesu TP, a to i při vysokých OVK. $S$ růstem teploty podlážky se TP dále snižovala, takže na podlážce $38^{\circ} \mathrm{C}$ teplé významně poklesla pod úroveň dosahovanou $\mathrm{v}$ termoneutrálním prostředí. Teplota podlážky $40{ }^{\circ} \mathrm{C} \mathrm{k}$ dalšímu poklesu TP již nevedla.

$\mathrm{Z}$ výsledků vyplývá, že $\mathrm{v}$ komplexním tepelném prostředí se rovněž termoneutrální podmínky stávají parametrem komplexnějším, čemuž musí odpovídat i způsob jejich determinace.

Влияние изменений комплексно определенной термической среды на температуру тела, температуру кожи и энергетический мегализм поросят

Температура тела (ТT) поросят в возрасте $1-25$ суток при изменении охлаждающих свойств метаболической камеры (ОСК), подогреваемой водой до 40 , а также $60,90,120$ и 150 Вт.м- ${ }^{2}$, фиксируемых датчиком электрического динамического кататермометра (ЭДК), явно не менялась. Только у поросят в возрасте $1-5$ суток наблюдалась тенденция к понижению. Температура кожи (ТК) в данных условиях явно понижалась до возраста 10 суток даже при нагреве поросят от настила температурой $34^{\circ} \mathrm{C}$. Повышение температуры настила до $36{ }^{\circ} \mathrm{C}$ или $38{ }^{\circ} \mathrm{C}$ даже при высоких ОСК 150 или 180 Вт.м-2 привело к быстрому увеличению и стабилизации (ТК) приблизительно до уровня, достигаемого в термонейтральной среде. По сравнению с данным уровнем на настиле $40{ }^{\circ} \mathrm{C}$ наблюдалось существенное повышение TK.

Теплопродукция (ТП) поросят в возрасте $1-5$ суток достигала самого низкого уровня при ОСК 60 и 90 Вт.м-2. Существенное увеличение наблюдалось при повышении ОСК до 120 и $150 \mathrm{Bт.м-2}$, а также при понижении ОСК до 40 Вт.м- ${ }^{2}$. Поросята в возрасте 6-10 суток отличались самой низкой ГП при ОСК 90 и 120 Вт.м-2. При понижении ОСК до 60 Вт.м-2 имела место тенденция к повышению ТП, при ОСК 150 Вт.м-2 наблюдалось явное 
повышение. ТП у поросят в возрасте $11-15$ суток существенно повышалась лишь при ОСЧ 180 Вт.м-2; изменения ОСК у поросят постарше не оказывали никакого влияния на ТП. Подогрев поросят настилом $34^{\circ} \mathrm{C}$ в первые две недели жизни выразился в резком понижении ТП даже при высоких ОСК. С увеличением температуры настила ТП постоянно понижалась, следовательно, на настиле $38{ }^{\circ} \mathrm{C}$ она доходила ниже уровня, достигаемого в термонейтральной среде. Температура настила $40{ }^{\circ} \mathrm{C}$ не вызывала уже далыгейшего понижения теплопродукции.

Из результатов следует, что термонейтральные условия в комплексной термической среде становятся более комплексным параметром, которому должен соответствовать также способ их определения.

\section{References}

ČESNEK, J. - NOVÁK, L.: Electrical katathermometer, its construction and some examples of its use in physiological experiment. Physiol. bohemoslov., 20, 1971:57.

HELLER, H. C. - GLOTZBACH, S. F.: Thermal influences on sleep. In Proceedings of the XXVIII. International Congress of Physiological Sciences, Budapest 1980, p. 136.

HOLUB, A.: Váhové přírůstky selat chovaných na semisyntetické vysokokalorické dietě v prvním měsíci života. Živočišná výroba, 36, 1964a: 539-544.

HORNE, J. A.: Factors relating to energy conservation during sleep in mammals. Physiol. Psychol., 5, 1977: 403-408.

KOTRBǍCEK, V. - HOLUB, A. - CESNEK, J.: Elektrický dynamický katatermometr a tepelné prostředí v porodnách prasat. Vet. Med., Praha, 24, 1979: 725-730.

KOTRBÁČEK, V. - HOLUB, A. - CESNEK, J.: Elektrický dynamický katatermometr a tepelné podmínky $\mathrm{v}$ doupatech pro selata. Vet. Med., Praha, 24, 1979: 449-454.

KOTRBAČEK, V. - NAU, H. - R.: Changes in skin temperatures of sows after parturition. 1984. In press.

MgGINNIS, R. M. - MARLE, D. N. - GAJAN, V. K. - PRINCE, J. J. - PRITCHETT, J. F.: The effects of floor temperature, supplemental heat and drying at birth on neonatal swine. J. Anim. Sci., 53, 1981: 1424-1431.

MOUNT, L. E.: Heat transfer between animal and environment. Proc. Nutr. Soc., 37, 1978: $21-27$.

ON 734517 Projektování staveb pro chov prasat, 1976. 